\title{
The utilization of protein and excretion of uric acid in germ-free and conventional chicks
}

\author{
By D. N. SALTER, MARIE E. COATES AND D. HEWITT \\ National Institute for Research in Dairying, Shinfield, Reading RG2 $9 A T$
}

(Received 17 May 1973-Accepted 22 November 1973)

\begin{abstract}
I. The influence of the gut microflora on protein utilization has been investigated with a series of good- and poor-quality protein diets in germ-free (GF) and conventional (CV) chicks by the measurement of net protein utilization (NPU) and uric acid excretion.

2. The diets used were: $280 \mathrm{~g}$ protein per $\mathrm{kg}$ dict containing unheated or heat-damaged albumen (100 g/kg), casein $(80 \mathrm{~g} / \mathrm{kg}$ ) and gelatin ( $100 \mathrm{~g} / \mathrm{kg})$; sesame protein $(220 \mathrm{~g} / \mathrm{kg})$; sesame protein $(220 \mathrm{~g} / \mathrm{kg})$ supplemented with lysine $(5 \mathrm{~g} / \mathrm{kg})$; freeze-dried cod muscle $(\mathrm{I} 60 \mathrm{~g} / \mathrm{kg})$; heat-damaged cod muscle ( $60 \mathrm{~g} / \mathrm{kg}$ ); mildly-steamed egg albumen ( $100 \mathrm{~g} / \mathrm{kg}$ ); heat-damaged egg albumen $(100 \mathrm{~g} / \mathrm{kg})$.

3. No significant differences in NPU values for the proteins measured in GF and CV chicks were found, with the exception of unsupplemented sesame protein, for which the NPU value was slightly higher in GF chicks.

4. The replacement of unheated egg albumen by heat-damaged egg albumen in the $280 \mathrm{~g}$ protein/ $\mathrm{kg}$ diet resulted in a decrease in uric acid excretion. With the cod-muscle diets, heat-damaging the protein caused an increase in uric acid excretion. Supplementing the sesame protein with lysine resulted in a decrease in uric acid excretion.

5. Excretion of uric acid tended to be higher in CV chicks than in GF chicks with all proteins except sesame protein, with which uric acid excretion was a little higher in GF chicks.

6. Endogenous nitrogen excretion was higher in GF than in CV chicks.

7. It is concluded that the gut microflora has little influence on the utilization of dietary protein by chicks, although it may modify the route of excretion of the $\mathrm{N}$ which survives digestion and reaches the lower gut.
\end{abstract}

It has been suggested by a number of authors that measurements of protein and amino acid digestibility by balance techniques might give misleading results as undigested protein and peptides could be broken down by micro-organisms in the lower gut and the nitrogenous products absorbed (Nesheim \& Carpenter, 1967; Payne, Combs, Kifer \& Snyder, 1968; Salter \& Coates, 1971; Carpenter, 1973). In experiments in which ${ }^{14} \mathrm{C}$-labelled egg white was fed to germ-free (GF) and conventional (CV) chicks (Salter \& Coates, I97I) we showed that nitrogen was separated from ${ }^{14} \mathrm{C}$ by the action of micro-organisms in the lower gut of $\mathrm{CV}$ chicks. It remained to be investigated whether such nitrogenous products, if absorbed, were of any benefit to the chick. The test for net protein utilization (NPU) takes account of both digestibility and retention of protein, being a measure of the proportion of the food $\mathrm{N}$ retained by the animal. It was therefore considered to be the most appropriate indicator of whether the host animal benefited, or otherwise, from the action of the microflora. In the experiments reported here, a range of good- and poor-quality proteins was given at various dietary levels to GF and CV chicks, and NPU was determined by $\mathrm{N}$ balance methods. 


\section{MATERIALS AND METHODS}

\section{Chicks}

The chicks used were Rhode Island Red $\times$ Light Sussex cross. Details of the rearing of GF chicks in Gustafsson isolators and of the corresponding CV chicks in a controlled-environment room have been previously described (Salter \& Coates, 1971). Chicks were kept in metabolism cages in pairs, an arrangement that has been found to encourage a more uniform feeding pattern.

\section{Diets}

The composition $(\mathrm{g} / \mathrm{kg})$ of the $\mathrm{N}$-free diet was: maize starch $879 \cdot 5$, salt mixture 60 , choline chloride ${ }^{\cdot} \cdot 5$, myoinositol I $\cdot 0$, vitamin supplement $8 \cdot 0$, maize oil $5 \circ$. In each $\mathrm{kg}$ diet the salt mixture provided: $\mathrm{CaCO}_{3}, \mathrm{r} 7 . \mathrm{I} \mathrm{g} ; \mathrm{KH}_{2} \mathrm{PO}_{4}, \mathrm{I} 3.3 \mathrm{~g} ; \mathrm{CaHPO}_{4} .{ }_{2} \mathrm{H}_{2} \mathrm{O}$, I7.I g; $\mathrm{NaCl}, 8.67 \mathrm{~g} ; \mathrm{MnSO}_{4} \cdot{ }_{4} \mathrm{H}_{2} \mathrm{O}, 27 \mathrm{O} \mathrm{mg} ; \mathrm{KI}, 37 \mathrm{mg} ; \mathrm{CuSO}_{4} \cdot{ }_{5} \mathrm{H}_{2} \mathrm{O},{ }_{1} 6 \mathrm{mg}$; $\mathrm{ZnSO}_{4} \cdot 7 \mathrm{H}_{2} \mathrm{O}$, г $30 \mathrm{mg} ; \mathrm{MgSO}_{4} \cdot \mathrm{H}_{2} \mathrm{O}, 2.67 \mathrm{~g} ; \mathrm{FeSO}_{4} \cdot{ }_{7} \mathrm{H}_{2} \mathrm{O}, 670 \mathrm{mg}$. Fat-soluble vitamins were dissolved in the maize oil and provided, per $\mathrm{kg}$ diet: cholecalciferol, $0.16 \mathrm{mg}$; menaphthone, $20 \mathrm{mg}$; $\alpha$-tocopheryl acetate, $40 \mathrm{mg}$ : Rovimix A325 (Roche Products, Welwyn Garden City, Herts) was added to supply $20 \mathrm{mg}$ retinol $/ \mathrm{kg}$. 'The vitamin supplement provided, per $\mathrm{kg}$ diet: calcium pantothenate, $60 \mathrm{mg}$; riboflavin, $24 \mathrm{mg}$; thiamin hydrochloride, $12 \mathrm{mg}$; pyridoxine hydrochloride, $16 \mathrm{mg}$; biotin, $800 \mu \mathrm{g}$; nicotinic acid, $160 \mathrm{mg}$; pteroylmonoglutamic acid, $6 \mathrm{mg}$; cyanocobalamin, $80 \mu \mathrm{g}$. The biotin was increased to $\mathrm{I} \cdot 6 \mathrm{mg} / \mathrm{kg}$ in the egg-white diets to counteract the effect of some remaining avidin activity. In the test diets the protein supplements were added at the expense of maize starch. The supplements $(\mathrm{g} / \mathrm{kg})$ were: $\operatorname{diet} \mathrm{A}$, egg albumen (100), casein (80) and gelatin ( 100$)$; diet $\mathrm{B}$, heat-damaged egg albumen $(100)$, casein (80) and gelatin (100); diet C, sesame meal (550, equivalent to $220 \mathrm{~g}$ protein); diet $\mathrm{D}$, sesame meal $\left(55^{\circ}\right)$ and L-lysine hydrochloride $(6.25)$; diet $\mathrm{E}$, freezedried cod muscle (I60); diet F, heat-damaged cod muscle (I60); diet G, mildlysteamed egg albumen (IOO); diet $\mathrm{H}$, heat-damaged egg albumen (IOO); diet $\mathrm{J}$, casein (180) and gelatin (100); diet $\mathrm{K}$, as A but with mildly-steamed albumen in place of unheated albumen. After the diets had been mixed they were granulated, packed into plastic bags, sealed and sterilized by $\gamma$-radiation at 5 Mrad.

Preparation of heat-damaged cod-muscle protein. The freeze-dried cod meal, prepared as described by Ford \& Salter (1966), was spread in layers about $5 \mathrm{~mm}$ deep on stainless-steel trays, covered with a larger tray, and autoclaved at $12 \mathrm{I}^{\circ}$ for $24 \mathrm{~h}$. The autoclaved meal was dried back to its original weight in a flow of air at $50^{\circ}$, then milled.

Preparation of heat-damaged egg albumen. Powdered air-dried egg albumen was heat-damaged by autoclaving in steam at $12 \mathrm{I}^{\circ}$ for $24 \mathrm{~h}$ in the manner previously described (Salter \& Coates, 1971).

Preparation of mildly-steamed egg albumen. In preliminary tests it was found that steaming egg albumen at $100^{\circ}$ for $5 \mathrm{~min}$ completely destroyed trypsin-inhibitor activity. The powdered egg albumen, which had been dried in an airflow at $45^{\circ}$, was 
spread in layers about $3 \mathrm{~mm}$ deep on stainless-steel trays and placed in the steam, in an autoclave previously heated to $100^{\circ}$, for $5 \mathrm{~min}$. The steamed egg albumen was dried back to its original weight in a flow of air at $45^{\circ}$, then milled.

\section{Collection of excreta}

The droppings from each pair of chicks were collected into $200 \mathrm{ml} 0.05 \mathrm{M}$-sulphuric acid in deep, stainless-steel trays beneath the metabolism cages. The acid prevented further microbial action in excreta from $\mathrm{CV}$ chicks and avoided loss of ammonia. Collections were removed daily and stored deep-frozen in screw-capped polyethylene or glass bottles. The $3 \mathrm{~d}$ collection for each pair of chicks was pooled and homogenized. Uric acid and $\mathrm{N}$ were determined either in the homogenate or in the soluble and insoluble fractions of the homogenate.

\section{Uric acid}

Uric acid was extracted from the homogenized excreta or the insoluble fraction as follows: samples ( $\mathrm{I} \mathrm{g}$ ) were made up to $25 \mathrm{ml}$ with 0.05 M-glycine buffer, $\mathrm{pH} 9$, transferred to $28 \mathrm{ml}$ screw-capped McCartney bottles and heated at $100^{\circ}$ for 20 $\mathrm{min}$ in a stcam autoclave to inactivate microbial uricase. The bottles were then placed in a heated water-bath at $60^{\circ}$ and subjected to end-over shaking for $\mathrm{x} h$. The suspensions were then filtered to provide a clear filtrate in which uric acid was determined. Recovery was checked by the inclusion of known weights of uric acid with several samples. The concentration of uric acid was determined by a uricase method using the Technicon AutoAnalyzer (Morgenstern, Flor, Kaufman \& Klein, 1966).

\section{Other analytical methods}

Total $\mathrm{N}$ was determined by a Kjeldahl micro- or semi-micro digestion procedure followed by measurement of the ammonium sulphate formed in a Technicon AutoAnalyzer (Technicon Instruments Co. Ltd, Basingstoke, Hants.). Trypsin inhibitor in egg white was measured by the method of Sambeth, Nesheim \& Serafin (1967). Available amino acids were measured by a microbiological method with Streptococcus zymogenes (Ford \& Salter, 1966).

\section{Calculation of NPU}

NPU is defined as the proportion of the food $\mathrm{N}$ that is retained by an animal. This can be expressed in terms of the difference between $\mathrm{N}$ intake and output, corrected for endogenous $\mathrm{N}$ excretion, i.e. $\mathrm{N}$ excreted during the period on a $\mathrm{N}$-free diet after a suitable period of adaptation:

$$
\mathrm{NPU}=\frac{\mathrm{N}_{\text {intake }}-\left[\left(\mathrm{N}_{\mathrm{F}}+\mathrm{N}_{\mathrm{U}}\right)-\left(\mathrm{N}_{\mathrm{F}, \text { endogenous }}+\mathrm{N}_{\mathrm{U} \text {, endogenous }}\right)\right]}{\mathrm{N}_{\text {intake }}},
$$

where the subscripts $\mathrm{F}$ and $\mathrm{U}$ stand for faecal and urinary, respectively. With the chick, faecal and urinary excretions are voided by a common route and it is not possible to make the corrections often applied to determinations of NPU in the rat, namely for body-weight in relation to endogenous urinary $\mathrm{N}$ and for food intake 
in relation to endogenous faecal $\mathrm{N}$. Thus, for the present work, in the above equation: $\mathrm{N}_{\text {intake }}=\mathrm{N}$ consumed in the protein diet during the $3 \mathrm{~d}$ test period; $\mathrm{N}_{\mathrm{F}}+\mathrm{N}_{\mathrm{U}}=$ total $\mathrm{N}$ excreted during the 3 d test period; $\left(\mathrm{N}_{\mathrm{F} \text {, endogenous }}+\mathrm{N}_{\mathrm{U} \text {, endogenous }}\right)=$ total $\mathrm{N}$ excreted by the same chicks during $3 \mathrm{~d}$ test periods on a $\mathrm{N}$-free diet. For the purpose of this work, which is a direct comparison of protein utilization between GF and CV birds fed under strictly similar conditions, this expression should give a satisfactory indication of any differences caused by the presence or absence of microflora.

\section{Experimental design}

In each experiment the chicks were housed in pairs in metabolism cages and the two members of each pair were fed alike. Measurements were not available for individuals and the basic experimental unit in each experimental design was a pair of chicks.

Two test proteins were compared in each experiment but each pair of chicks received only one test diet and the $\mathrm{N}$-free diet in sequence to enable the NPU value to be determined.

Because the experiments were done during the period of maximal growth of the chick it seemed likely that large differences in endogenous $\mathrm{N}$ excretion might be expected from one week to the next. To compensate for this a 'cross-over' type of design was used in the earlier experiments, whereby half the pairs of chicks on a particular test diet in a given environment received their test diet in the 3 rd week of age followed by a similar experimental period on $\mathrm{N}$-free diet (4th week), while the remaining pairs received their test diet and $\mathrm{N}$-free diet in reverse order. Although each experimental period lasted for $7 \mathrm{~d}$, droppings were collected only during the last $3 \mathrm{~d}$. Before the experimental periods (weeks 3 and 4 ) all chicks were given a common preliminary diet. In the first experiment all sixteen pairs of chicks (eight GF and eight $\mathrm{CV}$ ) were reared to $\mathrm{I}_{4} \mathrm{~d}$ on a preliminary diet, $\mathrm{A}$. In the following 2 weeks all pairs in each environment received the $\mathrm{N}$-free diet and one test diet (either $\mathrm{A}$ or $\mathrm{B})$, with half the pairs receiving their test diet in week 3 followed by the $\mathrm{N}$-free diet in week 4 , and the remaining pairs receiving their test diet and $\mathrm{N}$-free diet in reverse order. In the experiment with diets $\mathrm{G}$ and $\mathrm{H}$ a similar 'cross-over' procedure was adopted except that for the preliminary if $\mathrm{d}$ period all chicks (sixteen pairs) were reared on diet $K$, and then in subsequent stages diets $G$ and $H$ were introduced in the same manner as the test diets of the first experiment.

In an attempt to improve the precision of the determinations a 'sandwich' type of design was used for the remaining experiments. Eight pairs of GF and eight pairs of $\mathrm{CV}$ chicks were reared to $\mathrm{I}_{4} \mathrm{~d}$ on diet $\mathrm{J}$ and were then all transferred to the $\mathrm{N}$-free diet for the next $7 \mathrm{~d}$. They were then transferred to the test diets, four pairs in each environment receiving diet $\mathrm{E}$ and four pairs $\mathrm{F}$ for $7 \mathrm{~d}$. Finally, all pairs of chicks were returned to the $\mathrm{N}$-free diet for $7 \mathrm{~d}$ and further collections of excreta were made. The average of the $\mathrm{N}$ excreted during the two periods on $\mathrm{N}$-free $\operatorname{diet}\left(3^{\mathrm{rd}}\right.$ and $5^{\text {th }}$ weeks) was used as a measure of endogenous $\mathrm{N}$. In experiments with diets $\mathrm{C}$ and $\mathrm{D}$ a similar experimental design was followed, the diet for the first $\mathrm{I} 4 \mathrm{~d}$ being a standard chick mash as described by Coates \& Harrison (I959). 


\section{Statistical analysis}

In the analysis of variance of NPU and uric acid values in the 'sandwich' type of experiment, standard errors of diet or environmental effects were derived for the variation between pairs of chicks within environments and diets, with 12 degrees of freedom. In most of the corresponding 'cross-over' experiments, effects or interactions associated with periods (week 3 vs. week 4 ) were not significant and a similar error variance was appropriate, also with 12 degrees of freedom. For the analysis of NPU values of diets $\mathrm{G}$ and $\mathrm{H}$, however, a significant period effect (but no significant interaction with periods) was established, and standard errors for diet and environmental effects have been derived from the variation between pairs of chicks within diets, environments, and periods with only 8 degrees of freedom.

In the analysis of endogenous $\mathrm{N}$ excretion, the results for the four experiments were combined. The results for each pair of chicks in the 'sandwich' experiments for the periods before and after test diet were averaged. Standard errors of environmental differences were derived from the pooled variation between pairs of chicks within diets, environments, and experiments with 47 degrees of freedom due to one missing value.

\section{RESULTS}

\section{Influence of heat-treatments on availability of amino acids in egg white}

Table I shows the contents of total and available methionine, leucine, isoleucine, valine, histidine, arginine and tryptophan in the unheated, mildly-steamed and heatdamaged egg albumen used in diets A, B, G and $\mathrm{H}$. Only a slight reduction in the mean proportions of amino acids available (from 0.85 to 0.80 ) was caused by steaming for $5 \mathrm{~min}$, whereas there was a large decrease (to $0.4 \mathrm{I}$ ) in the proportion of amino acids available in the protein autoclaved for $24 \mathrm{~h}$.

\section{Influence of microflora and protein quality on NPU values}

Values for NPU in GF and $\mathrm{CV}$ chicks for the eight test diets, A-H, are given in Table 2. The precision of the two types of experiment, represented by diets A, B, G, H ('cross-over') and C, D, E, F ('sandwich') was similar. Although some differences in body-weight were observed between GF and CV chicks within experiments, they were neither large enough nor consistent enough to invalidate comparisons between NPU values in the two environments. The choice of proteins gave a wide range of NPU values. Within each pair of proteins there were large differences. The effect of heat-damaging egg albumen and freeze-dried cod muscle is clearly seen by comparing diets $\mathrm{B}, \mathrm{F}$ and $\mathrm{H}$ with $\mathrm{A}, \mathrm{E}$ and $\mathrm{G}$ respectively. With egg albumen alone, diets $G$ and $H$, the NPU values were consistent with the average amino acid availabilities in the microbiological assay (Table $\mathbf{r}$ ). Heat damage had a less marked effect, particularly in CV chicks, with diets $\mathrm{A}$ and $\mathrm{B}$ than with diets $\mathrm{E}$ and $\mathrm{F}$ and diets $\mathrm{G}$ and $H$. Diets $A$ and $B$ had the highest protein level and only one-third of this, the egg albumen, was subjected to heating. The NPU value of sesame meal was low but it was considerably improved by supplementation with lysine. 


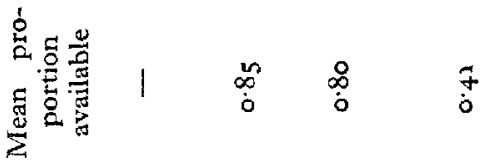

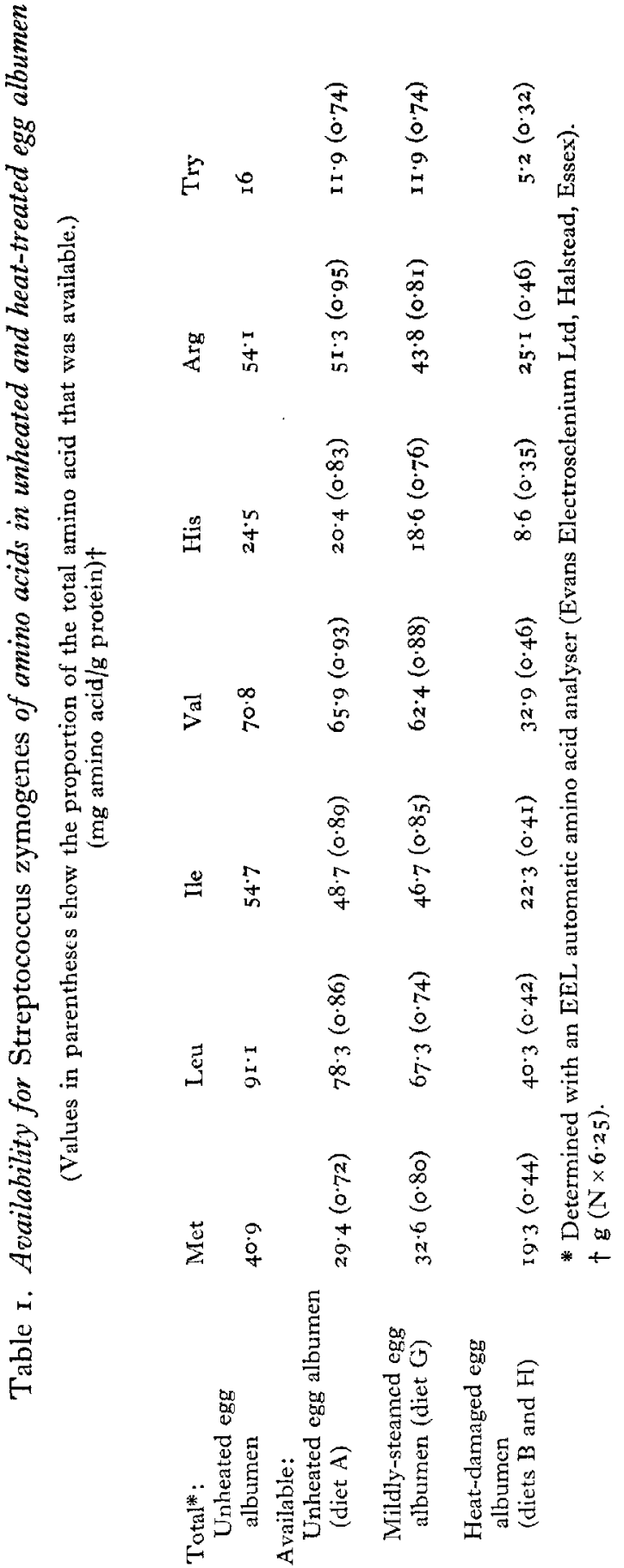


Vol. 3 I

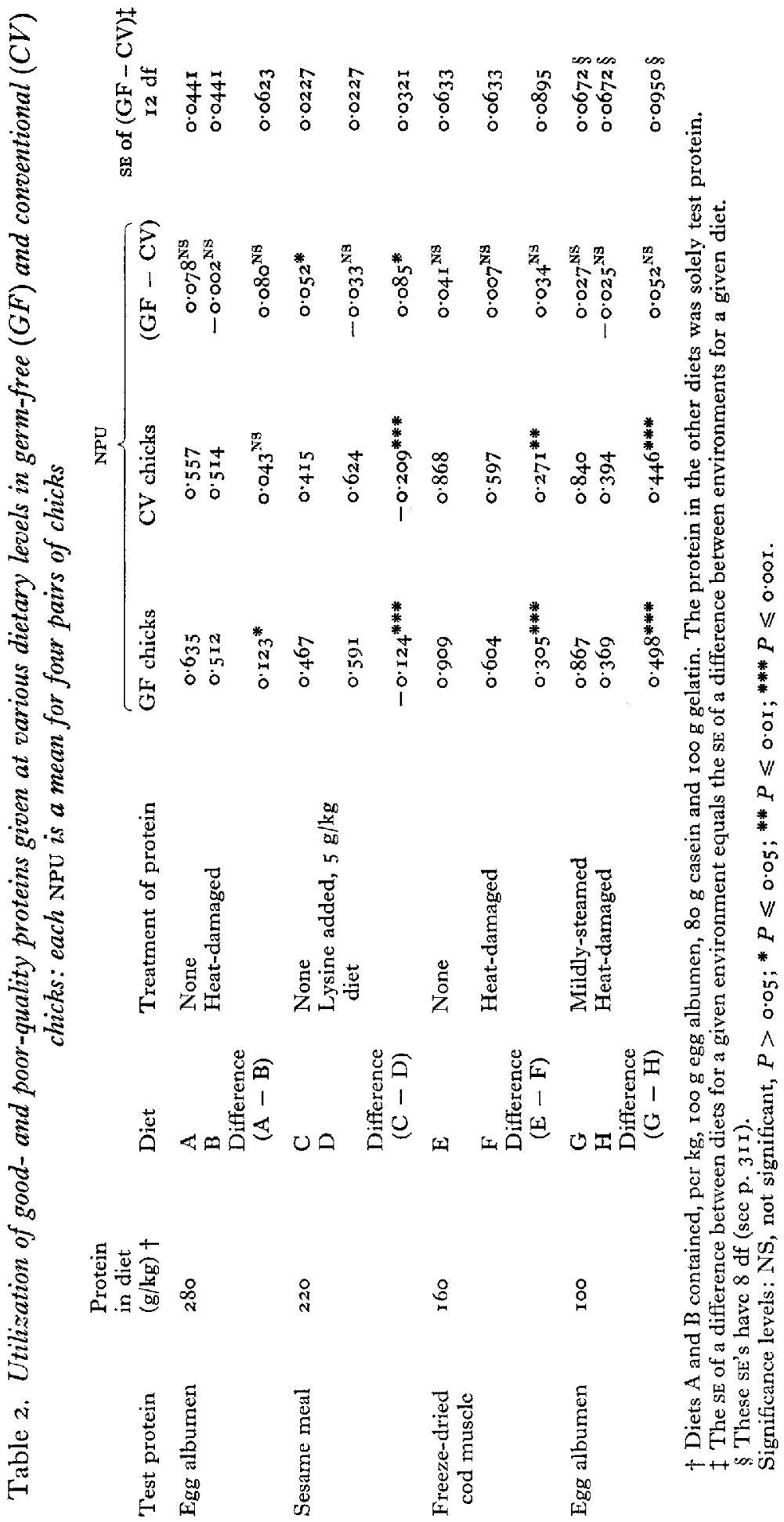




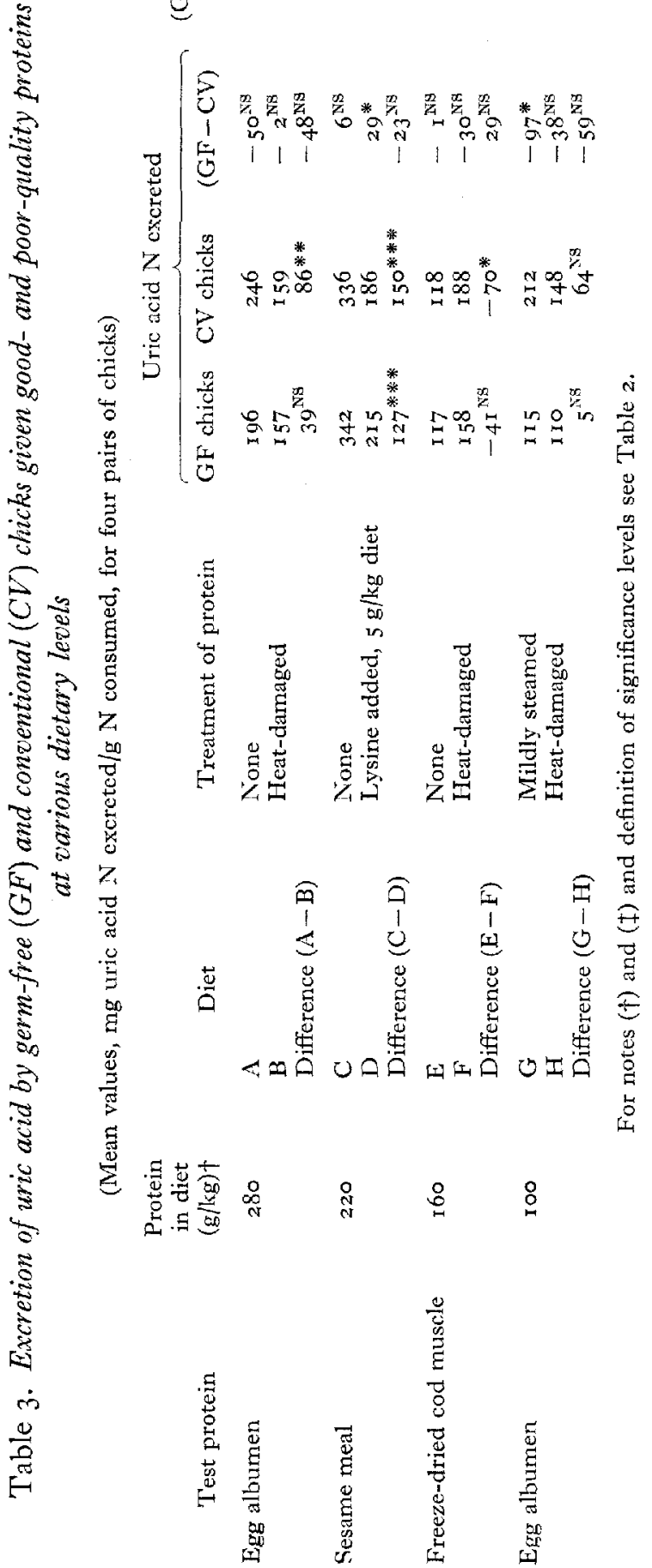


Table 4. Excretion of nitrogen (mg/g food eaten) by GF and CV chicks given a $N$-free diet

(In each experiment an environment mean is an average for eight pairs of chicks)

\begin{tabular}{|c|c|c|c|c|}
\hline \multirow[b]{2}{*}{$\begin{array}{l}\text { Corresponding test- } \\
\text { protein diets } \dagger\end{array}$} & \multicolumn{3}{|c|}{$\mathrm{N}$ excretion (mg/g food) } & \multirow{2}{*}{$\begin{array}{c}\text { SE of } \\
(\mathrm{GF}-\mathrm{CV}) \\
47 \mathrm{df}\end{array}$} \\
\hline & GF & $\mathrm{CV}$ & $\begin{array}{l}\text { Difference } \\
(\mathrm{GF}-\mathrm{CV})\end{array}$ & \\
\hline$A, B$ & 5.94 & 5.66 & $0.28^{\mathrm{NS}}$ & $x \cdot 226$ \\
\hline C, D & $9 \cdot 32$ & 7.61 & $\mathrm{I} \cdot 7 \mathrm{I}^{\mathrm{NS}}$ & I. 226 \\
\hline$E, F$ & II. 58 & $8 \cdot 52$ & $3 \cdot 06^{*}$ & $I=226$ \\
\hline $\mathrm{G}, \mathrm{H}$ & 10.487 & 8.57 & $I^{\circ} \cdot 9 I^{\mathrm{NS}}$ & $I \cdot 269$ \\
\hline Mean & $9 \cdot 33$ & 7.59 & $\mathbf{I}-74^{* *}$ & 0.618 \\
\hline
\end{tabular}

For definition of significance levels see Table 2 .

+ For details of diets see p. 308.

$\ddagger$ One missing value.

The microflora had little effect on protein utilization. The NPU values obtained with egg albumen and cod muscle, and the effects of heat damage, were similar in GF and CV chicks. With unsupplemented sesame meal, however, the NPU value for GF chicks was slightly but significantly higher than that for CV chicks whereas with the supplemented meal there was little evidence of an effect of environment.

\section{Influence of the microflora and protein quality on uric acid excretion}

The amounts of uric acid $\mathrm{N}$ excreted by $\mathrm{GF}$ and $\mathrm{CV}$ chicks during the test periods on these proteins are recorded in Table 3. Heat-damaging egg albumen, diet B, resulted in a decrease in uric acid excretion (significant in CV chicks). Similarly with diet $\mathbf{H}$, heat damage caused lower uric acid excretion, but the effect was less clear. In contrast there was an increase in uric acid excretion of $\mathrm{CV}$ chicks given heatdamaged compared with the undamaged cod-muscle protein. There were similar trends in GF chicks when egg albumen and cod muscle were damaged. The high digestibility and poor retention of $\mathrm{N}$ from sesame meal was demonstrated by the high excretion of uric acid by chicks given this protein, and clear improvement in quality was shown by the large decrease in uric acid excretion when the diet was supplemented with lysine.

The microflora had only small effects on uric acid excretion. With undamaged albumen, uric acid excretion tended to be higher in CV than in GF chicks but the effect was only significant with diet $G$. With heat-damaged albumen and both types of cod muscle, uric acid excretion was similar in both environments. With sesame meal supplemented with lysine, uric acid excretion was slightly but significantly higher in GF than in $\mathrm{CV}$ chicks.

\section{Influence of the microflora on endogenous $N$ excretion}

In Table 4 , the $\mathrm{N}$ excreted per $\mathrm{g}$ food eaten by GF and $\mathrm{CV}$ chicks for the periods on the $\mathrm{N}$-free dict during each experiment is recorded. The mean endogenous $\mathrm{N}$ excretion was significantly higher in GF than in CV chicks, although in individual 
experiments the difference was statistically significant in only one. Significant interaction between environmental effect and experiments was not established.

\section{DISCUSSION}

It has been suggested (Salter, 1973) that the various possible effects of the microflora in the lower gut (release of amino acids from undigested peptides, deamination of amino acids, incorporation of amino acids into microbial protein, and impairment of intestinal absorption) would not effect NPU of a good-quality protein given at a level in excess of requirements. They might, however, give rise to either a decrease or an increase in NPU with less-than-adequate or poor-quality dietary proteins, depending on which effect(s) preponderated, and might influence the partition of $\mathrm{N}$ excreted between faeces and urine. In the present experiments an attempt has been made to demonstrate differences in NPU that could be caused by the action of the microflora, by giving good-and poor-quality proteins at more than adequate, optimal and suboptimal levels to GF and CV chicks. Poor-quality proteins were represented by sesame protein, which is poorly utilized on account of amino acid deficiency, and by egg albumen and cod muscle that had been damaged by prolonged autoclaving. Of the latter proteins a high proportion would have remained undigested and passed into the lower gut, where the microbial population is greatest. Although the results clearly showed the differences in nutritional quality of the various proteins, the only significant difference between GF and CV chicks in NPU values was found with sesame meal. Even here the difference was small and a preliminary evaluation of further studies with sesame meal does not appear to confirm this result (Hewitt, unpublished results). Thus it may be concluded that, for these particular diets, the microflora had no important effect on the total nutritional value of dietary proteins to the birds. It should not be assumed, however, that the microflora has no influence on the course of digestion and utilization of protein. Some of the possible activities of the microflora such as release of amino acids from undigested peptides may benefit the host to only a limited extent. The amino acids may be utilized by the host but part may also be deaminated or incorporated into microbial protein and excreted. Thus effects on NPU may oppose each other so that there is littlc or no net change.

Separate analyses of faecal and urinary $\mathrm{N}$ are not possible in the intact bird but, since most of the uric acid in avian droppings is of urinary origin, the uric acid excretion values in Table 3 give some idea of the relative excretion of urinary $\mathrm{N}$ among the different test groups. According to Nesheim \& Carpenter (1967) the proportion of the total urinary $\mathrm{N}$ contributed by uric acid may vary with dietary factors, including the type of protein. Thus, strict comparisons are only permissible between birds in the two environments on the same diet. Nevertheless, the gross differences in the uric acid excretion observed between birds given the different diets did reflect the nutritional qualities of the test proteins. A high level of excretion of uric acid by $\mathrm{CV}$ chicks given the high-protein $(280 \mathrm{~g} / \mathrm{kg})$ diet $\mathrm{A}$, containing $100 \mathrm{~g}$ unheated egg albumen $/ \mathrm{kg}$, clearly shows that although much of the $\mathrm{N}$ was absorbed, it was surplus to requirements for growth and maintenance and was therefore excreted. This 
is also supported by the absence of an environment effect. However, the results with the low-protein diet $\mathrm{G}$, containing $100 \mathrm{~g}$ mildly-steamed egg albumen $/ \mathrm{kg}$, appear to ${ }^{\mathrm{s}} \mathrm{conflict}$ with this, since in this case a significant increase in uric acid excretion occurred in $\mathrm{CV}$ compared with GF chicks. It is possible that the mild steaming of the egg albumen used in this experiment had altered the physical properties of part of the protein to make it less soluble, as undigested granules of egg albumen were observed in excreta of GF chicks. After prolonged wetting during passage through the intestines, this portion of the protein may have become susceptible to bacterial attack. The significant decrease in uric acid excretion by $\mathrm{CV}$ chicks caused by heat-damage of the egg albumen reflects poorer absorption of protein with a consequently smaller surplus available for excretion. With the diet containing $160 \mathrm{~g}$ undamaged cod-muscle protein $/ \mathrm{kg}$, however, low uric acid excretion indicated efficient utilization of the absorbed $\mathrm{N}$. The higher uric acid excretion in chicks given the heat-damaged cod-muscle protein indicated that some of the protein $\mathrm{N}$ had been absorbed but was not retained.

With the exception of the sesame meal experiment, there was a tendency towards higher uric acid excretion by $\mathrm{CV}$ chicks. This may be indicative of the absorption of nitrogenous products of no nutritional value released by the microflora from protein residues. The studies of Reitnour \& Salisbury ( 1972 ) on the digestion and utilization of caecally infused protein in the horse are in accord with this view. The results of Erbersdobler \& Riedel (1972) in an investigation of the influence of the gut microflora on the digestibility of the amino acids in two test proteins (unheated and severely heated isolated soya-bean protein) are in general agreement with our findings. When given at the level of $380 \mathrm{~g} / \mathrm{kg}$ diet to $\mathrm{GF}$, monoinfected, polyinfected and $\mathrm{CV}$ chicks there were no significant differences between GF, infected and CV groups.

Miller ( 1967 ) observed greater excretion of $\mathrm{N}$ by GF than by $\mathrm{CV}$ chicks given a $\mathrm{N}$-free diet and this is confirmed by the present experiments. It may be that there is a somewhat greater loss of $\mathrm{N}$ from the tissues of birds in the GF environment. Alternatively the lower excretion by $\mathrm{CV}$ birds could be accounted for by reduced faecal excretion due to microbial action on endogenous proteins in the gut, with subsequent recycling of part of the $\mathrm{N}$. The latter suggestion seems more likely and is supported by the results of amino acid analysis of excreta from GF and CV chicks given a $\mathrm{N}$-free diet (Salter, unpublished results).

The greater endogenous $\mathrm{N}$ excretion in GF compared with $\mathrm{CV}$ chicks has a bearing on the NPU results because in the calculation of NPU, N excretion of chicks when on test diet is corrected for endogenous $\mathrm{N}$ losses. However, the contribution of the endogenous $\mathrm{N}$ term is small and any effect of this difference would be within the experimental error of the NPU determination.

The diets we examined varied widely in the quantity and quality of the proteins they contained, but with only one possible exception, we detected no marked effect of the microflora on their nutritional value. The tendency for CV chicks to excrete more uric acid than their GF counterparts suggested that microbial activity may have increased digestibility, as proposed by Nesheim \& Carpenter (I967) and others. Nevertheless, this effect was too small to be of much biological importance. The 
greater loss of endogenous $\mathrm{N}$ by the GF birds is being further investigated, since it might prove of importance in conditions of extreme protein deprivation.

The authors thank Dr J. W. G. Porter for helpful advice and discussions during the course of this work, $\mathrm{Mr}$ J. P. Fordham for the care and maintenance of the germfree birds, Mr K. J. Scott for the microbiological assays of available amino acids, and Mrs K. E. A. Smith and Mrs C. A. Ewart for skilled technical assistance. We are grateful to Mr D. R. Westgarth for the statistical analysis of results.

\section{REFEREN CES}

Carpenter, K. J. (1973). In Proteins in Human Nutrition p. 343 [J. W. G. Porter and B. A. Rolls, editors]. London and New York: Academic Press.

Coates, M. E. \& Harrison, G. F. (1959). Br. F. Nutr. I3, 345.

Erbersdobler, H. \& Riedel, G. (1972). Arch. Gefügelk. 6, 218.

Ford, J. E. \& Salter, D. N. (1966). Br. F. Nutr. 20, 843 .

Miller, W. S. (1967). Proc. Nutr. Soc. 26, x.

Morgenstern, S., Flor, R. V., Kaufman, J. H. \& Klein, B. (1966). Clin. Chem. 12, 748.

Nesheim, M. C. \& Carpenter, K. J. (I967). Br. F. Nutr, z1, 399.

Payne, W. L., Combs, G. F., Kifer, R. R. \& Snyder, D. G. (rg68). Fedn Proc. Fedn Am. Socs exp. Biol. 27, 1999.

Reitnour, C. M. \& Salisbury, R. L. (1972). F. Anim. Sci. 35, I 190.

Salter, D. N. (1973). Proc. Nutr. Soc. 32,65.

Salter, D. N. \& Coates, M. E. (1971). Br. F. Nutr. 26, 55.

Sambeth, W., Nesheim, M. C. \& Serafin, J. A. (1967). $\mathscr{F} . ~ N u t r .92,479$. 